\title{
An Assessment of a Community-Based, Forest Restoration Programme in Durban (eThekwini), South Africa
}

\author{
Lutendo F. Mugwedi ${ }^{1, *}$ (D), Mathieu Rouget ${ }^{1,2}$, Benis Egoh ${ }^{1,3}$, Sershen ${ }^{4}$, Syd Ramdhani ${ }^{4}$ (D), \\ Rob Slotow ${ }^{4,5}$ and Jorge L. Rentería ${ }^{1,6}$ \\ 1 School of Agriculture, Earth and Environmental Sciences, University of KwaZulu-Natal, Private Bag X1, \\ Scottsville 3209, South Africa; mathieu.rouget@cirad.fr (M.R.); BEgoh@csir.co.za (B.E.); \\ jlrenteriab@gmail.com (J.L.R.) \\ 2 CIRAD, UMR PVBMT, F-97410 St Pierre, La Réunion, France \\ 3 Natural Resources and the Environment, Council for Scientific and Industrial Research, P.O. Box 320, \\ Stellenbosch 7599, South Africa \\ 4 School of Life Sciences, University of KwaZulu-Natal, Westville 3630, South Africa; \\ naidoose@ukzn.ac.za (S.); ramdhani@ukzn.ac.za (S.R.); slotow@ukzn.ac.za (R.S.) \\ 5 Department of Genetics, Evolution and Environment, University College, London WC1E 6BT, UK \\ 6 Invasive Species Programme, South African National Biodiversity Institute, Kirstenbosch Research Centre, \\ Claremont 7735, South Africa \\ * Correspondence: lutendo.mug@gmail.com; Tel.: +27-33-260-6346
}

Academic Editors: Mark S. Ashton and Timothy A. Martin

Received: 28 April 2017; Accepted: 13 July 2017; Published: 28 July 2017

\begin{abstract}
The restoration of degraded forests to enhance biodiversity, ecosystem services, as well as climate change mitigation and adaptation is now a major priority in cities around the world. This study evaluated the success of the Buffelsdraai Landfill Site Community Reforestation Project in Durban, South Africa, by assessing ecological attributes. Measures of plant richness, diversity, vegetation structure, invasive alien plants (IAPs) and ecological processes were contrasted across a chronosequence of habitats under restoration (0-year-old, 3-year-old and 5-year-old) and compared with a reference forest habitat (remnant natural forest). Native tree species recruitment and vegetation structure increased with restoration age. Ecological processes, represented by the composition of pollination and seed dispersal traits in all of the habitats under restoration, were similar to the reference habitat. However, low tree density and an increase in IAP cover with an increase in restoration age were identified as threats to reforestation success. We recommend enrichment planting and an effective IAP management strategy to promote more rapid habitat restoration while reducing site maintenance costs. Enrichment planting should not only focus on increasing tree species density and richness, but also on the inclusion of species with missing pollination and seed dispersal categories.
\end{abstract}

Keywords: ecosystem processes; invasive alien plants; pollination; restoration success; seed dispersal; species diversity; vegetation structure

\section{Introduction}

Continuous environmental degradation, presently occurring at alarming rates around the world, has motivated restoration efforts that aim to enhance biodiversity and ecosystem functioning and to ensure continued provision of ecosystem services [1,2]. Furthermore, owing to a rapid expansion of urban populations and the threats of climate change, green infrastructure investment has become a necessity in large and developing cities across the globe [3,4]. In the quest of creating sustainable 
and resilient cities, governments are investing in the restoration of natural capital to improve human well-being [3].

An important objective of restoration initiatives is to create an ecosystem that is self-sustaining and resilient to disturbance [5]. This can be achieved by creating an ecosystem that is closer or more similar to the former natural habitat (commonly labelled 'reference habitat') in terms of plant diversity, plant traits and functional group diversity [6,7]. Self-sustaining and resilient forest ecosystems are characterized by a species-rich and multi-layered vegetation structure with key ecological processes such as litter accumulation, pollination and seed dispersal [8,9]. Assessment of vegetation structure provides information on habitat suitability for fauna, such as insects, birds, reptiles and small mammals, and ecosystem productivity $[8,10]$. Multi-layered vegetation structure protects the forest from natural hazards [8] such as invasive alien plant (IAP) invasion [11].

Unfortunately, due to insufficient monitoring, the actual number of tree species and their density in most restoration projects are unknown $[12,13]$. During the establishment phase, planted trees may also die; native tree recruitment may fail; and sites can be invaded by alien plants and weeds, indicating the need for post-planting monitoring and management. Assessing reforestation success and challenges would provide beneficial insight, which could guide the necessary management interventions and inform best practices in the future [14,15]. However, most restoration assessments often focus on species establishment (usually of indicator species), with at least one aspect of ecological processes necessary for long-term persistence of the ecosystem [16,17]. Furthermore, numerous studies have shown that the inclusion of a variety of indicators such as vegetation structure, species diversity and ecological process in assessing restoration success is imperative for comprehensive assessment of restoration outcomes (e.g., [16,18]).

An understanding of key ecological processes is essential to maximize the efficiency of restoration processes and managed restored systems (e.g., $[19,20]$ ). In this regard, plant litter is considered to be a valuable indicator to measure as it is a key factor in structuring many plant communities (e.g., seedling recruitment) due to its ability to modify micro-environmental conditions [21]. Litter that accumulates on the forest floor forms an essential part of nutrient cycling [22,23], which is necessary for the long-term stability of an ecosystem [24]. Pollination, fruit production, seed dispersal and seedling establishment are also key ecological processes ensuring the long-term stability of the forest ecosystem $[25,26]$. Pollination has received little attention in restoration studies $[17,19]$. Pollination and seed dispersal are dependent on forest fauna such as insects, birds and mammals [27]. In most forest systems, recovery is limited by poor seed dispersal [28,29], and consequently, seed dispersal is often assessed by measuring seedling density and diversity (e.g., $[29,30])$.

Restoration success can be hampered by invasive alien plants due to their competitive growth and reproductive strategies [31,32]. Challenges posed by IAPs during habitat restoration are encountered particularly when species invade and establish large populations [32]. High IAP cover can compromise native seedling establishment [4]. Understanding IAPs' distribution and expansion following forest restoration is the initial step towards the development of an effective control strategy and a determinant of when and where the control strategy should be implemented [33].

The Buffelsdraai Landfill Site, situated within the eThekwini Municipal Area (the municipality manages the metropolitan region including the city of Durban) (EMA), north of Durban in KwaZulu-Natal (KZN), South Africa, was formerly under dryland sugarcane cultivation for over a century and is now under restoration [34]. The restoration is a climate change-driven project, which aims to offset the carbon footprint associated with the city's hosting of the 2010 FIFA World Cup, enhance biodiversity and ecosystem services, and provide socioeconomic benefits to local communities [34]. The planting commenced in 2009, and since it is still in the establishment phase, there is a need to assess its success in terms of ecosystem functioning and to recommend the necessary management interventions to levels of functionality. Using a chronosequence (0-year-old, 3-year-old and 5-year-old) of land under reforestation, we assessed early progress of forest restoration in terms of tree species diversity, vegetation structure and ecological processes (e.g., pollination) needed for the 
creation of a self-sustaining, functional forest ecosystem that is resilient to disturbance and the presence of IAPs. The indicators assessed were compared to the reference (natural forest remnants) habitat in order to gauge restoration success. Additionally, various recommendations are made for future restoration planning within the EMA and other forest restoration projects elsewhere in the world.

\section{Methods}

\subsection{Study Area}

The study was conducted at Buffelsdraai Landfill Site $\left(29.62961^{\circ} \mathrm{S} ; 30.980392^{\circ} \mathrm{E}\right)$, the largest regional solid waste landfill in KZN, South Africa. The active landfill site is 116 ha and has a buffer zone of 757 ha of which 580 ha (former low productive dryland sugarcane field) has been planted with over 51 indigenous tree species. An average of 1000 (in the dry habitat) and 2000 (in the wet habitat) tree saplings per hectare was planted in the wet season, commencing from 2009-2010 (November-February) to 2014-2015 at a rate of about 100 ha per year [34]. Species were planted randomly, but there is a lack of record on the number of tree species planted in the 3- and 5-year-old habitats, except for the 0-year-old habitat that we assessed one month post planting. Furthermore, dead saplings' replacement was done some months after planting in the 3- and 5-year-old habitat [34]. Therefore, species richness and diversity results from these two habitats should be interpreted with caution. The remainder of the buffer zone is characterized by mosaic patches of indigenous forest, woodlands and grasslands, with almost all of the sites being invaded by alien plants [35]. The vegetation, broadly classified as KwaZulu-Natal Coastal Belt (grassland and subtropical forest), is highly transformed and fragmented with little formal protection. The vegetation type as a whole is classified as endangered [36]. The remnants of indigenous forest form part of eastern scarp forest, usually located at an altitude of 100-1000 $\mathrm{m}$ [37], and is described as a refuge forest that survived the last glacial maximum $(\approx 18,000 \mathrm{BP})$ [38]. Approximately $15-31 \%$ of eastern scarp forest has been lost due to land use change (e.g., clearing for agriculture) and non-sustainable harvesting of forest products by rural communities, but it should be noted that this estimate is quite dated [37]. This has resulted in fragmentation between patches and an increased edge ecotone [39]. The remnants of natural indigenous forest around the Buffelsdraai Landfill Site were used as a reference habitat, a requirement in reforestation assessment studies of this nature $[16,17]$.

Prior to the start of this reforestation project, tree species composition of the surrounding forest patches (reference habitat, $105.8 \mathrm{ha}$ ) was assessed to guide the selection of species to be planted in the restoration site based on the species importance value (after MacFarlane et al. [35]). This restoration initiative is a community-based forest restoration project, named the 'Buffelsdraai Landfill Site Community Reforestation Project'. Tree saplings for planting were supplied by tree-preneurs (community tree-growers) within the Buffelsdraai, Osindisweni and KwaMashu local communities (peri-urban areas) who source the seeds from the reference habitat and forest patches within a 50-km radius of the site (after MacFarlane et al. [35]). These communities are plagued by poverty and unemployment [40].

The topography of the study area is characterized by undulating slopes (200-325 $\mathrm{m}$ in altitude). A glacial conglomerate parent material that is base rich, hard and resistant to weathering, the Dwyka Tillite, is the dominant geology within the site [41]. The upland area is characterized by shallower $(20-40 \mathrm{~cm})$ lithosol soil. The soil is probably shallower as a result of higher soil erosion caused by runoff, exacerbated by cultivation. The lowland area is characterized by deeper $(60-110 \mathrm{~cm})$ acrisol soil. The deeper soil is probably as a result of the deposition of materials from the upper slopes [41]. The upland area is drier, while the lowland area is wetter [41]. As a result, upland and lowland areas were subjected to different planting densities, 1000 and 2000 trees per ha, respectively [34]. 


\subsection{Data Collection}

Vegetation sampling was done within three habitats under restoration, planted in 2009-2010 ('5-year-old habitat'), 2011-2012 ('3-year-old habitat') and 2014-2015 ('0-year-old habitat'), and in the surrounding natural forest patches (reference habitat). The surrounding natural forest patches were approximately 40, 300 and $250 \mathrm{~m}$ from the 0 -, 3- and 5-year-old habitats, respectively.

\subsubsection{Vegetation Composition and Structure}

Microtopographic positions (upland and lowland areas) within a site affect hydrologic conditions [42]. As a result, within a species, individual tree growth rates may vary significantly [42,43]. To minimize the confounding effects of soil moisture and planting densities, upland and lowland areas were selected within each habitat under restoration (0-, 3- and 5-year-old) based on a soil survey done on the entire Buffelsdraai Landfill Site [41] and in the reference habitat, in the upper slopes and riparian area. Twelve plots of $400 \mathrm{~m}^{2}(20 \times 20 \mathrm{~m})$ (six plots in both upland and lowland areas) were randomly established within each restoration and reference habitat for vegetation sampling. All planted individuals within the habitats under restoration were counted. In the reference habitat, all trees excluding saplings (individuals with less than a 4-cm stem diameter at breast height) were counted. Across all habitats, the percentage of tree canopy cover (visually estimated by one person to avoid estimation bias) and tree height were measured. Tree species within each plot were identified and assigned to species successional types (pioneer vs. understorey vs. climax) using published accounts [44,45]. The percentage of herbaceous layer cover (graminoids, forbs and herbaceous climbers) was visually estimated in four $4 \mathrm{~m}^{2}$ subplots that were established within each plot. Subplots were located at each cardinal point of the plot, $4 \mathrm{~m}$ from the plot boundary. In this study, climbers were defined as plants that use other plants or objects to support themselves in growing towards sunlight or into positions that permit attraction of pollinators or seed dispersers [44].

\subsubsection{Invasive Alien Plants}

Only woody IAPs were considered, since their vigorous growth poses a huge threat to restoration success [46]. Percentage IAP cover was visually estimated within the subplots. The IAPs present in the subplots were identified and categorised using the National Environmental Management: Biodiversity Act (NEMBA), 2004 (Act No. 10 of 2004) Alien and Invasive Species List, 2016 [47], which includes three invasive alien categories, 1-3.

\subsubsection{Ecological Processes}

Forest litter accumulation was assessed by measuring litter cover and depth [22,23]. Within each subplot, the litter percentage of cover was visually estimated. Litter depth was measured to the nearest millimetre using a ruler.

Pollination and seed dispersal traits for each tree species sampled were determined on the basis of field observations, herbarium specimens and published descriptions [44,45]. Species were assigned to either one or a combination of six pollination categories, namely bee, beetle, bird, butterfly, fly or 'other' pollination category. The 'other' pollination category included species with unknown pollinators and one wind-pollinated species that was represented by one individual in the reference habitat. Additionally, species were assigned to either one or a combination of five seed dispersal categories, namely ballistic, bird, mammal, wind or 'other' dispersal category (species with unknown dispersal agents) [48,49], based on field observations, herbarium specimens and published data [44,45].

To understand the influence of restoration age on native tree recruitment, all woody species (referred to as seedlings) greater than $0.05 \mathrm{~m}$ in height were counted and identified within each subplot $\left(4 \mathrm{~m}^{2}\right)$. 


\subsection{Data Analysis}

The upland and lowland areas' data were analysed separately to avoid the confounding effect of microtopographic position (upland and lowland area) and the consequent different tree planting densities. All statistical computations were performed in R statistics [50].

\subsubsection{Species Richness and Diversity}

The EstimateS package [51] was used to construct sample-based species-accumulation curves. To achieve this, we pooled all of the species data per habitat. Two non-parametric estimators for abundance data, abundance-based coverage estimator (ACE) and Chao1 (a species richness estimator named afer Chao who developed in 1984) were used to estimate species richness [52]. The level of sampling completeness was computed by dividing the number of species found by the projected number of species using ACE and Chao1 [53].

Simpson's evenness index $\left(E_{1 / D}\right)$ and Simpson's diversity index $(D)$ were used as measures of tree diversity. Simpson diversity was computed with the EstimateS package [51] using species abundance data [54]. Simpson's evenness was computed as $E_{1 / D}=(1 / D) / S$, where $D$ represents Simpson's diversity index and $S$ represents the number of species [54]. Species richness (observed), evenness and diversity indices were compared across habitats using generalized linear models (GLMs), the Gaussian family (MASS package [55]), followed by the Tukey post hoc test to separate habitats with significant differences at $p<0.05$ (multcomp package [56]).

\subsubsection{Species Composition and Abundance}

To assess whether restoration habitats are progressing towards or diverging from the reference habitat in terms of species composition and abundance, a non-metric multidimensional scaling (NMDS) ordination analysis based on the Bray-Curtis index was used (Vegan: Community Ecology package [57]). Two analyses of species composition were performed. The first analysis assessed species composition in the upland and lowland area of each habitat, separately. In the second analysis, both the upland and lowland areas within each habitat were combined in order to assess species composition per habitat. Patterns of species similarity shown in the NMDS were confirmed using analysis of similarity (ANOSIM) (Vegan: Community Ecology package [57]).

\subsubsection{Vegetation Structure and Litter Accumulation}

GLMs were applied using the Gaussian family (MASS package [55]) to compare tree stem density, tree height and litter depth across habitats. GLMs were also applied using the logit function, the quasibinomial family (MASS package [55]), to compare the percentage of tree canopy cover, herbaceous layer cover, IAP cover and litter layer cover, as well as species successional type across habitats. Species successional type data were calculated in terms of proportional values per plot, i.e., the number of individuals within a successional type divided by the total number of individuals within the plot. Statistical analyses were followed by a Tukey post hoc test to separate habitats with significant differences at $p<0.05$ (multcomp package [56]).

\subsubsection{Pollination and Seed Dispersal}

Community-weighted mean trait values for pollination and seed dispersal traits were computed [58,59]. Traits were computed in terms of proportion per plot using species abundance. Species abundance data were used, as they show the pollination/seed dispersal category state similarity of individuals, independent of species identity, within plots and habitats [48]. We first compared each pollination and seed dispersal category across habitats using the GLMs, logit function, the quasibinomial family (MASS package [55]), followed by a Tukey post hoc test (multcomp package [56]). We then assessed the pollination and seed dispersal categories' composition across habitats using the 
NMDS, followed by the ANOSIM, to separate habitats with significant differences at $p<0.05$ (Vegan: Community Ecology package [57]).

\subsubsection{Plant Regeneration}

Seedling recruitment levels were not compared across habitats statistically since only a few species with low densities were recruited in the restored habitats. Only the mean density per subplot $\left(4 \mathrm{~m}^{2}\right)$ of recruited species across the habitats was computed.

\section{Results}

\subsection{Plant Species Richness and Diversity}

Species accumulation curves based on ACE and Chao1 showed that increased sampling would have revealed more species (Figure S1). Sampling completeness was adequate in all cases, with values ranging from $75.6-82.8 \%$ in the zero-year-old habitat, $93.7-95.3 \%$ in the three-year-old habitat, $88.9-91.6 \%$ in the five-year-old habitat and $87.2-87.5 \%$ in the reference habitat. Tree species richness differed across habitats. In the upland area, 29, 22, 29 and 48 tree species were recorded in the 0-, 3-, 5 -year-old and the reference habitats, respectively. In the lowland area, 18, 31, 36 and 40 tree species were recorded in the $0-, 3-, 5$-year-old and the reference habitats, respectively (see Table S1). When data for all of the species were pooled per habitat, 36, 40, 44 and 70 species were recorded in the 0-, 3-, 5-year-old and reference habitats, respectively. The shared species among restored habitats and between restored and reference habitats ranged from $24-40$ tree species. Overall, 59 tree species were recorded in habitats under restoration, of which 49 species were shared with the reference habitat (Table S1).

Species richness, Simpson's evenness and Simpson's diversity varied significantly across habitats (Table 1). In the upland area, the reference habitat had the highest species richness, significantly $\left(\chi^{2}=9.36 ; p<0.05\right)$ higher than the three-year-old habitat; however, richness among the habitats under restoration was statistically comparable. Species evenness was highest in the zero-year-old habitat, significantly $\left(\chi^{2}=8.97 ; p<0.05\right)$ higher than the five-year-old habitat. Species were most diverse in the reference habitat, being significantly $\left(\chi^{2}=9.95 ; p<0.05\right)$ greater than the three- and five-year-old habitats.

Table 1. Measures of species richness, diversity and species successional type proportion across habitats (mean $\pm \mathrm{SD}$ ).

\begin{tabular}{|c|c|c|c|c|c|c|}
\hline \multicolumn{7}{|c|}{ Upland Area } \\
\hline \multirow[b]{2}{*}{ Habitat } & \multicolumn{3}{|c|}{ Diversity Indices } & \multicolumn{3}{|c|}{ Tree Successional Type } \\
\hline & $\begin{array}{l}\text { Species } \\
\text { Richness }\end{array}$ & $\begin{array}{l}\text { Simpson's } \\
\text { Evenness }\end{array}$ & $\begin{array}{c}\text { Simpson's } \\
\text { Diversity }\end{array}$ & Pioneer & Understorey & Climax \\
\hline 0 -year-old & $11.3 \pm 1.86 \mathrm{ab}$ & $0.87 \pm 0.03 a$ & $2.9 \pm 0.47 \mathrm{ab}$ & $0.59 \pm 0.05 a$ & $0.17 \pm 0.05 \mathrm{ab}$ & $0.27 \pm 0.03 a$ \\
\hline 3-year-old & $8.6 \pm 3.55 b$ & $0.83 \pm 0.04 \mathrm{ab}$ & $1.9 \pm 0.85 b$ & $0.54 \pm 0.20 \mathrm{a}$ & $0.05 \pm 0.06 \mathrm{a}$ & $0.40 \pm 0.22 \mathrm{ab}$ \\
\hline 5-year-old & $10.1 \pm 4.16 \mathrm{ab}$ & $0.78 \pm 0.07 b$ & $2.2 \pm 0.85 b$ & $0.51 \pm 0.12 \mathrm{a}$ & $0.15 \pm 0.09 \mathrm{ab}$ & $0.32 \pm 0.10 \mathrm{ab}$ \\
\hline Reference & $14.1 \pm 2.85 a$ & $0.84 \pm 0.06 \mathrm{ab}$ & $3.7 \pm 0.56 a$ & $0.26 \pm 0.11 b$ & $0.23 \pm 0.13 b$ & $0.50 \pm 0.09 b$ \\
\hline \multicolumn{7}{|c|}{ Lowland Area } \\
\hline Habitat & $\begin{array}{c}\text { Species } \\
\text { Richness }\end{array}$ & $\begin{array}{l}\text { Simpson's } \\
\text { Evenness }\end{array}$ & $\begin{array}{c}\text { Simpson's } \\
\text { Diversity }\end{array}$ & Pioneer & Understorey & Climax \\
\hline 0 -year-old & $6.0 \pm 0.89 a$ & $0.90 \pm 0.02 a$ & $1.4 \pm 0.26 a$ & $0.53 \pm 0.08 \mathrm{a}$ & $0.18 \pm 0.02 \mathrm{a}$ & $0.27 \pm 0.10 \mathrm{a}$ \\
\hline 3-year-old & $12.6 \pm 2.58 b$ & $0.80 \pm 0.06 b$ & $2.8 \pm 0.57 b$ & $0.63 \pm 0.09 \mathrm{a}$ & $0.11 \pm 0.07 \mathrm{a}$ & $0.25 \pm 0.08 \mathrm{a}$ \\
\hline 5-year-old & $11.3 \pm 3.26 b$ & $0.89 \pm 0.04 a$ & $2.7 \pm 0.72 b$ & $0.57 \pm 0.10 \mathrm{a}$ & $0.16 \pm 0.07 \mathrm{a}$ & $0.25 \pm 0.04 \mathrm{a}$ \\
\hline Reference & $11.16 \pm 3.18 b$ & $0.87 \pm 0.05 \mathrm{ab}$ & $2.8 \pm 0.60 \mathrm{~b}$ & $0.59 \pm 0.33 a$ & $0.07 \pm 0.04 a$ & $0.32 \pm 0.27 \mathrm{a}$ \\
\hline
\end{tabular}

Different letters indicate significant difference across habitats at $p<0.05$. 
In the lowland area, the zero-year-old habitat had the lowest species richness, significantly $\left(\chi^{2}=21.66 ; p<0.05\right)$ lower than all of the other habitats. The three-year-old habitat had the lowest species evenness, significantly $\left(\chi^{2}=12.87 ; p<0.01\right)$ lower than the zero- and five-year-old habitats. Species diversity showed a similar trend to species richness $\left(\chi^{2}=25.55 ; p<0.01\right)$.

\subsection{Species Abundance and Composition}

In the upland area, the NMDS ordination showed that habitats under restoration clustered together (Figure 1a), and this was confirmed by the analysis of similarity (ANOSIM), which showed that habitats under restoration were more similar in terms of species composition and abundance. The reference habitat was significantly $(F=6.241 ; p<0.01)$ different from the habitats under restoration. In the lowland area, the NMDS ordination showed the separation of habitats with low similarity (Figure 1b). The ANOSIM confirmed that habitats were significantly different $(F=21.080, p<0.01)$ except the five-year-old and reference habitats. For overall species composition per habitat, the NMDS showed variation across the habitats (see Figure S2), except between the zero- and three-year-old habitats. The ANOSIM showed that the zero- and three-year-old habitats were similar and significantly different $(F=21.740 ; p<0.05)$ from the five-year-old and the reference habitats, which were themselves similar.
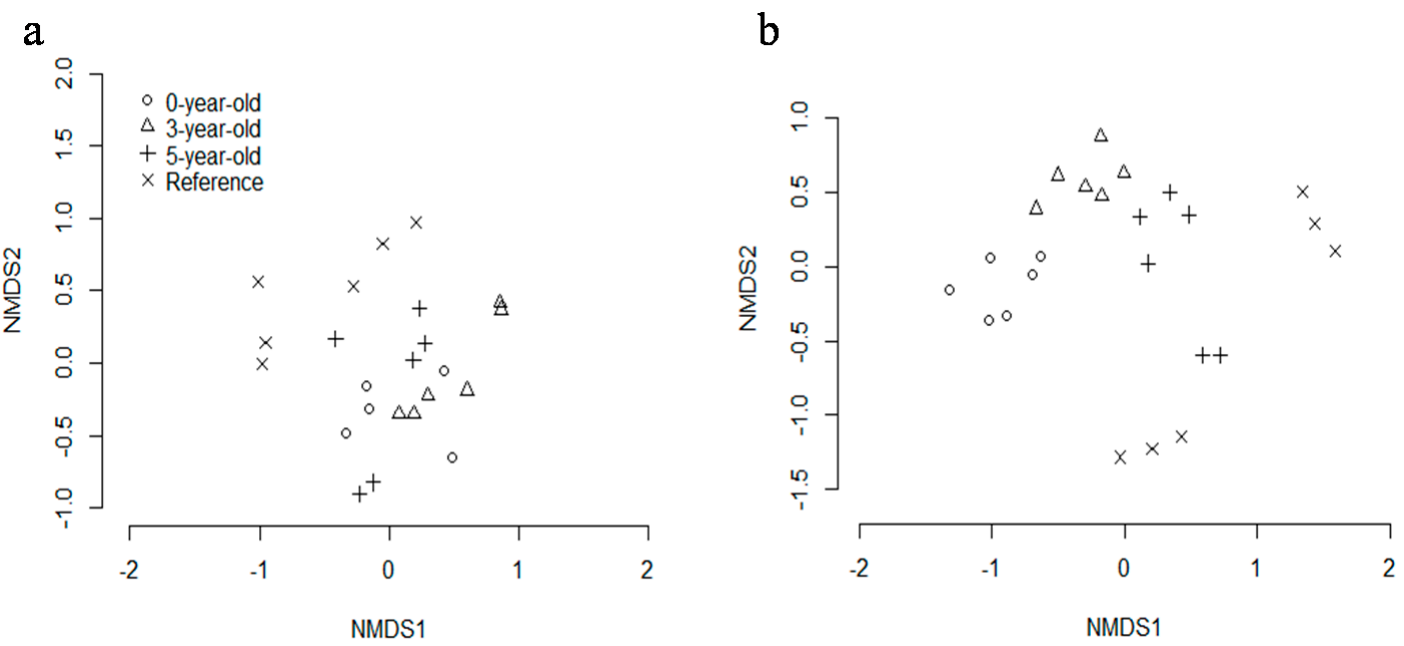

Figure 1. Non-metric multidimensional scaling (NMDS) ordination plot showing tree species composition in the (a) upland and (b) lowland areas. The NMDS was based on the Bray-Curtis similarity index computed using species abundance data.

\subsection{Vegetation Structure}

Species successional type proportion in the upland area varied significantly across habitats while no significant variation occurred in the lowland area (Table 1). In the upland area, pioneer species were most abundant in habitats under restoration, significantly $\left(\chi^{2}=20.44 ; p<0.01\right)$ greater than the reference habitat. The reference habitat had the highest climax and understorey species richness, significantly $\left(\chi^{2}=9.76 ; p<0.05\right.$ and $\chi^{2}=11.62 ; p<0.05$, respectively) greater than the zero- and three-year-old habitats, respectively.

Tree density, height and canopy cover and herbaceous layer cover varied significantly across habitats (Table 2). In the upland area, tree density was statistically comparable across habitats. Unsurprisingly, the reference habitat had the tallest trees, significantly $\left(\chi^{2}=104.7 ; p<0.01\right)$ taller than the other habitats. Tree height in the three- and five-year-old habitats was statistically comparable. Tree canopy cover varied significantly $\left(\chi^{2}=43.72 ; p<0.01\right)$ across habitats. The reference habitat had the highest cover, followed by the 5-, 3- and then 0-year-old habitats. Herbaceous layer cover was statistically comparable across habitats. In the lowland area, the three-year-old habitat had the highest 
tree density, significantly $\left(\chi^{2}=12.76 ; p<0.01\right)$ higher than all of the other habitats. Tree density per ha in the zero-year-old habitat was much lower (mean: 783 trees/ha) than the expected average density of 2000 trees per ha for the lowland area. Tree height and canopy cover showed a similar trend to the upland area $\left(\chi^{2}=112.70 ; p<0.01\right.$ and $\chi^{2}=206.36 ; p<0.01$, respectively). The reference habitat had the lowest herbaceous layer cover, significantly $\left(\chi^{2}=18.48 ; p<0.01\right)$ lower than the zero- and three-year-old habitats. Herbaceous layer cover was not statistically different across the habitats under restoration.

Table 2. Measures of vegetation structure and litter accumulation (mean $\pm \mathrm{SD}$ ).

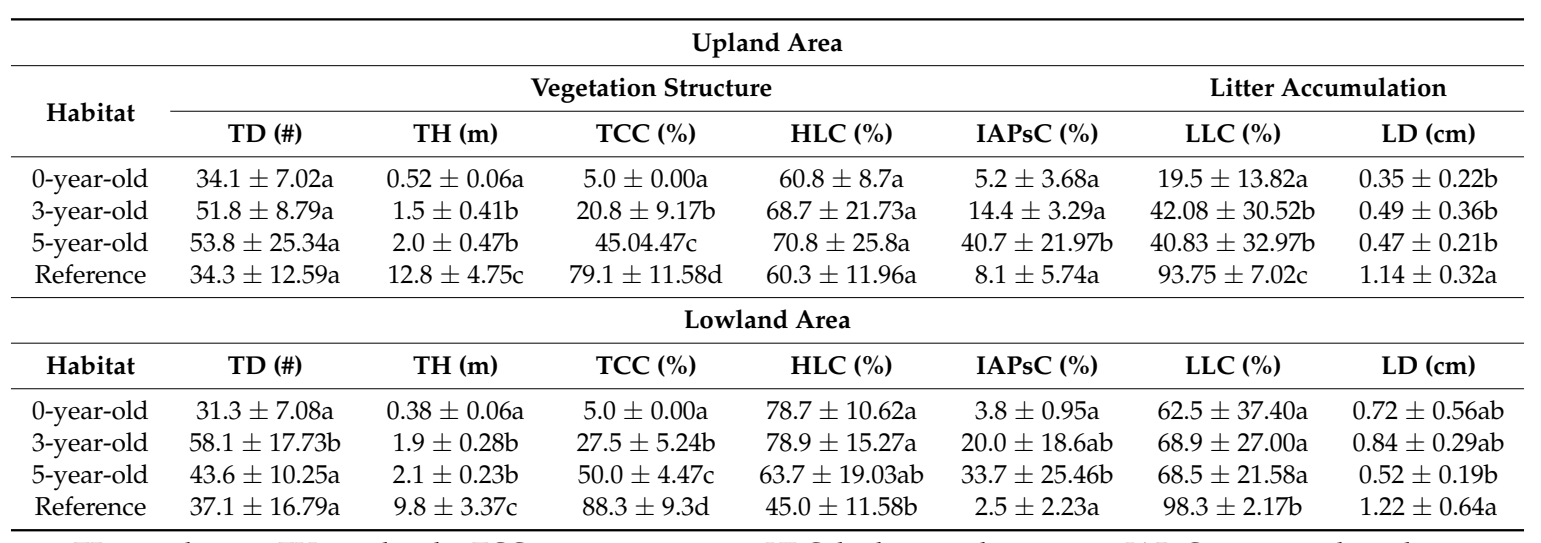

TD, tree density; TH, tree height; TCC, tree canopy cover; HLC, herbaceous layer cover; IAPsC, invasive alien plants cover; LLC, litter layer cover; LD, litter depth. Different letters indicate a significant difference across habitats at $p<0.05$.

\subsection{Invasive Alien Plants}

Five aggressive/widely-spread woody IAPs in South Africa were recorded (see Table S3), with Chromolaena odorata (L.) King and Robinson (Asteraceae) being the most common invader. The IAP cover increased with restoration age in both the upland and lowland areas (Table 2). In the upland area, IAP cover in the five-year-old habitat was significantly $\left(\chi^{2}=43.72 ; p<0.01\right)$ greater than the other habitats. In the lowland area, IAP cover in the five-year-old habitat was significantly $\left(\chi^{2}=17.18\right.$; $p<0.01)$ greater than in the zero-year-old and the reference habitat.

\subsection{Ecological Processes}

Litter accumulation varied significantly across habitats (Table 2). In the upland area, the reference habitat had the highest litter layer cover, significantly $\left(\chi^{2}=31.77 ; p<0.01\right)$ higher than all of the habitats under restoration. Among the habitats under restoration, the zero-year-old habitat had the lowest litter cover, significantly $\left(\chi^{2}=31.77 ; p<0.01\right)$ lower than the three- and five-year-old habitats. The reference habitat also had the deepest litter, significantly $\left(\chi^{2}=27.17 ; p<0.01\right)$ deeper than the habitats under restoration; however, litter depth was statistically comparable among the habitats under restoration. In the lowland area, the reference habitat had the highest litter layer cover, significantly $\left(\chi^{2}=11.32 ; p<0.05\right)$ higher than the habitats under restoration; however, litter layer cover among the habitats under restoration was statistically comparable. The reference habitat had the deepest litter, but was only significantly $\left(\chi^{2}=10.26 ; p<0.05\right)$ deeper than the five-year-old habitat. Litter depth among the habitats under restoration was statistically comparable.

In the upland area, pollination categories were statistically comparable among the habitats under restoration; however, significant differences occurred between the habitats under restoration and the reference habitat, in some categories (Table 3). Bee-pollinated species were most abundant in the reference habitat, significantly $\left(\chi^{2}=13.35 ; p<0.01\right)$ higher than the five-year-old habitat. Bird-pollinated species were most abundant in the zero- and five-year-old habitats, significantly $\left(\chi^{2}=11.36 ; p<0.01\right)$ higher than the reference habitat. Fly-pollinated species were most abundant in 
the five-year-old habitat, significantly $\left(\chi^{2}=10.13 ; p<0.05\right)$ higher than the reference habitat. The NMDS ordination for pollination trait composition showed that the zero- and three-year-old habitats were closer to the reference habitat in the ordination space, but the three-year-old habitat was also close to the five-year-old habitat (Figure 2a). This was confirmed by the ANOSIM, which showed that the zero-, three-year-old and reference habitats were similar, and the five 5-year-old habitat was only significantly $(F=8.42 ; p<0.01)$ different from the zero-year-old and the reference habitats.

a

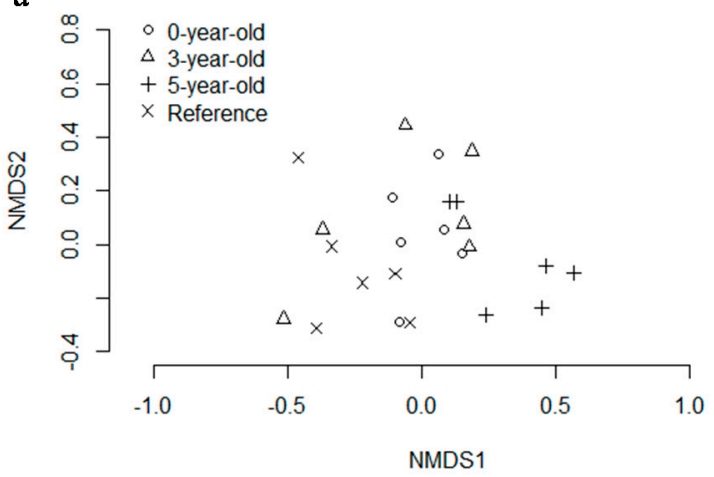

b

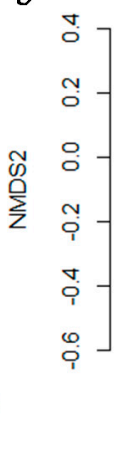

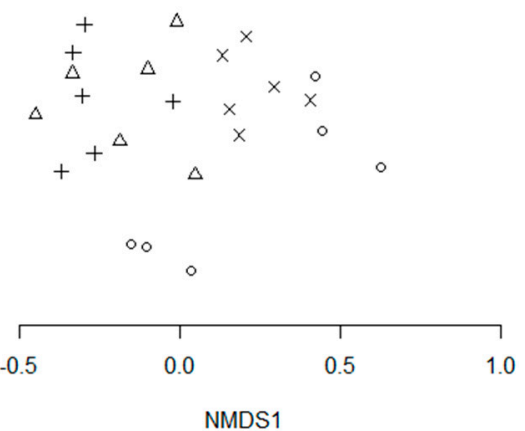

Figure 2. The NMDS ordination plot showing the species pollination traits in the (a) upland and (b) lowland areas. The NMDS was based on the Bray-Curtis similarity index computed using species abundance data.

In the lowland area, some pollination categories varied significantly, while some were statistically comparable across habitats (Table 3). Bee-pollinated species were most abundant in the zero-year-old habitat, but only significantly $\left(\chi^{2}=18.63 ; p<0.01\right)$ higher than the three- and five-year-old habitats. Bird-pollinated species were most abundant in the five-year-old habitat, but only significantly $\left(\chi^{2}=44.64, p<0.01\right)$ higher than the zero-year-old and the reference habitats. Butterfly-pollinated species were most abundant in the five-year-old reference habitats, but only significantly $\left(\chi^{2}=20.78\right.$; $p<0.01)$ higher than the zero-year-old habitat. Fly-pollinated species were most abundant in the three- and five-year-old habitats, but only significantly $\left(\chi^{2}=11.09 ; p<0.05\right)$ higher than the reference habitat. The 'other' pollination category was most abundant in the reference habitat, but only significantly $\left(\chi^{2}=9.24 ; p<0.05\right)$ higher than the zero-year-old habitat. The NMDS ordination showed that the zero-year-old habitat was close to the reference habitat and the three-year-old habitat close to the five-year-old habitat (Figure 2b). The ANOSIM confirmed that the zero-year-old and the reference habitats were similar and significantly $(F=9.34 ; p<0.01)$ different from the three- and five-year-old habitats, which were themselves similar.

Seed dispersal categories were not statistically different across habitats in the upland area, except mammal-dispersed species. In the lowland area, only three categories differed significantly across habitats (Table 3). The five-year-old habitat had the lowest abundance of mammal-dispersed species, but only significantly $\left(\chi^{2}=11.97 ; p<0.05\right)$ different from the reference habitat. In the upland area, the NMDS ordination for seed dispersal trait composition showed that all of the habitats were closer to each other (Figure 3a); the ANOSIM also showed that all of the habitats were similar. In the lowland area, ballistic-dispersed species were most abundant in the reference habitat, but only significantly $\left(\chi^{2}=12.04 ; p<0.01\right)$ higher than the zero-year-old habitat. Bird-dispersed species were most abundant in the zero-year-old habitat, but only significantly $\left(\chi^{2}=13.22 ; p<0.01\right)$ higher than the five-year-old and the reference habitats. Mammal-dispersed species were most abundant in the zero-year-old habitat, significantly $\left(\chi^{2}=14.22 ; p<0.01\right)$ higher than all other habitats. The NMDS ordination showed no clear separation among the habitats (Figure 3b). However, the ANOSIM showed that all habitats were similar. 
a

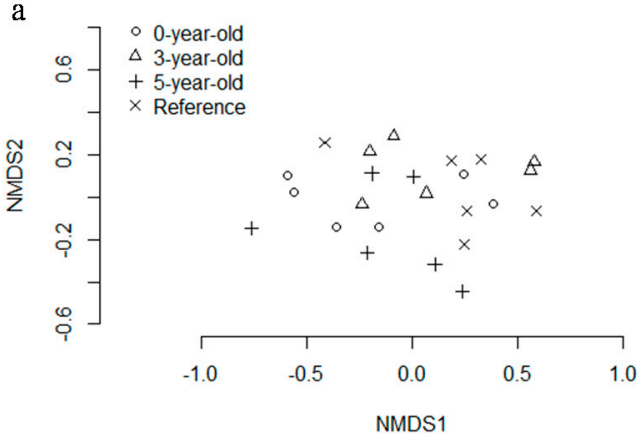

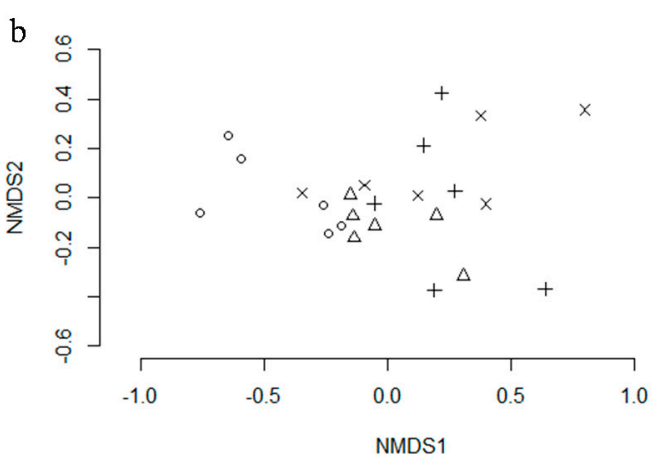

Figure 3. The NMDS ordination plot showing the species seed dispersal trait composition in the (a) upland and (b) lowland areas. The NMDS was based on the Bray-Curtis similarity index computed using species abundance data.

Native tree seedling recruitment increased with restoration age (Table 4). In the upland area, two, one, eight and 21 species were recorded in the 0-, 3-, 5-year-old and the reference habitats, respectively. In the lowland area, three, 12 and 23 species were recorded in the three-, five-year-old and the reference habitats, respectively. The dominant seedling species were Dalbergia obovata E.Mey. (Fabaceae), Combretum molle R.Br. ex G.Don (Combretaceae), Dalbergia armata E.Mey. (Fabaceae) and Kraussia floribunda Harv. (Rubiaceae) in the reference habitat, Diospyros lycioides Desf. (Ebenaceae) in the five-year-old habitat and Searsia rehmanniana (Engl.) Moffet (Anacardiaceae) in both the zero- and three-year-old habitats. Bird-dispersed species were the most dominant across all habitats, followed by mammal-dispersed species. 
Table 3. Species pollination and seed dispersal categories proportion across habitats (mean \pm SD).

\begin{tabular}{|c|c|c|c|c|c|c|c|c|c|c|c|}
\hline \multicolumn{12}{|c|}{ Upland Area } \\
\hline \multirow{2}{*}{ Habitat } & \multicolumn{6}{|c|}{ Pollination Categories } & \multicolumn{5}{|c|}{ Seed Dispersal Categories } \\
\hline & Bee & Beetle & Bird & Butterfly & Fly & 'Other' & Ballistic & Bird & Mammal & Wind & 'Other' \\
\hline 0 -year-old & $0.40 \pm 0.15 \mathrm{ab}$ & $0.06 \pm 0.02 a$ & $0.29 \pm 0.06 a$ & $0.02 \pm 0.01 \mathrm{a}$ & $0.35 \pm 0.08 \mathrm{ab}$ & $0.30 \pm 0.11 \mathrm{a}$ & $0.15 \pm 0.07 a$ & $0.40 \pm 0.20 \mathrm{a}$ & $0.24 \pm 0.18 \mathrm{ab}$ & $0.35 \pm 0.16 a$ & $0.13 \pm 0.02 a$ \\
\hline 3-year-old & $0.37 \pm 0.20 \mathrm{ab}$ & $0.07 \pm 0.02 \mathrm{a}$ & $0.20 \pm 0.15 \mathrm{ab}$ & $0.02 \pm 0.01 \mathrm{a}$ & $0.36 \pm 0.14 \mathrm{ab}$ & $0.35 \pm 0.16 a$ & $0.12 \pm 0.10 \mathrm{a}$ & $0.55 \pm 0.35 \mathrm{a}$ & $0.35 \pm 0.07 \mathrm{ab}$ & $0.28 \pm 0.06 a$ & $0.04 \pm 0.01 \mathrm{a}$ \\
\hline 5-year-old & $0.26 \pm 0.02 b$ & $0.09 \pm 0.04 a$ & $0.29 \pm 0.10 \mathrm{a}$ & $0.03 \pm 0.01 \mathrm{a}$ & $0.54 \pm 0.14 \mathrm{a}$ & $0.25 \pm 0.18 a$ & $0.20 \pm 0.04 \mathrm{a}$ & $0.44 \pm 0.26 a$ & $0.17 \pm 0.13 b$ & $0.31 \pm 0.11 \mathrm{a}$ & $0.08 \pm 0.03 a$ \\
\hline Reference & $0.54 \pm 0.04 \mathrm{a}$ & $0.07 \pm 0.02 \mathrm{a}$ & $0.13 \pm 0.05 \mathrm{~b}$ & $0.06 \pm 0.01 \mathrm{a}$ & $0.30 \pm 0.16 \mathrm{~b}$ & $0.27 \pm 0.12 \mathrm{a}$ & $0.13 \pm 0.1 \mathrm{a}$ & $0.55 \pm 0.18 \mathrm{a}$ & $0.43 \pm 0.13 \mathrm{a}$ & $0.25 \pm 0.14 a$ & $0.11 \pm 0.09 \mathrm{a}$ \\
\hline \multicolumn{12}{|c|}{ Lowland Area } \\
\hline Habitat & Bee & Beetle & Bird & Butterfly & Fly & 'Other' & Ballistic & Bird & Mammal & Wind & 'Other' \\
\hline 0 -year-old & $0.58 \pm 0.14 a$ & $0.15 \pm 0.11 \mathrm{a}$ & $0.04 \pm 0.01 \mathrm{a}$ & $0.01 \pm 0.00 \mathrm{a}$ & $0.33 \pm 0.14 \mathrm{ab}$ & $0.13 \pm 0.05 a$ & $0.01 \pm 0.00 \mathrm{a}$ & $0.66 \pm 0.17 \mathrm{a}$ & $0.58 \pm 0.20 \mathrm{a}$ & $0.17 \pm 0.13 a$ & $0.02 \pm 0.01 \mathrm{a}$ \\
\hline 3-year-old & $0.39 \pm 0.11 b c$ & $0.08 \pm 0.01 \mathrm{a}$ & $0.28 \pm 0.18 b$ & $0.04 \pm 0.03 b$ & $0.40 \pm 0.08 \mathrm{~b}$ & $0.24 \pm 0.11 \mathrm{ab}$ & $0.16 \pm 0.11 \mathrm{ab}$ & $0.59 \pm 0.07 a b$ & $0.24 \pm 0.11 b$ & $0.30 \pm 0.06 a$ & $0.08 \pm 0.05 a$ \\
\hline 5-year-old & $0.32 \pm 0.10 c$ & $0.15 \pm 0.03 a$ & $0.31 \pm 0.03 b$ & $0.06 \pm 0.04 b$ & $0.40 \pm 0.13 b$ & $0.27 \pm 0.08 \mathrm{ab}$ & $0.24 \pm 0.15 b$ & $0.35 \pm 0.13 b$ & $0.24 \pm 0.18 b$ & $0.31 \pm 0.03 a$ & $0.09 \pm 0.06 \mathrm{a}$ \\
\hline Reference & $0.53 \pm 0.10 \mathrm{ab}$ & $0.07 \pm 0.08 \mathrm{a}$ & $0.04 \pm 0.01 \mathrm{a}$ & $0.06 \pm 0.02 b$ & $0.22 \pm 0.04 a$ & $0.31 \pm 0.10 \mathrm{~b}$ & $0.28 \pm 0.10 \mathrm{~b}$ & $0.38 \pm 0.26 \mathrm{~b}$ & $0.28 \pm 0.18 b$ & $0.30 \pm 0.10 \mathrm{a}$ & $0.03 \pm 0.01 \mathrm{a}$ \\
\hline
\end{tabular}

Different letters indicate significant difference across habitats at $p<0.05$.

Table 4. Mean woody seedlings density (seedlings or saplings per $4 \mathrm{~m}^{2}$ ) and their dispersal agent categories across habitats.

\begin{tabular}{|c|c|c|c|c|c|c|c|c|c|}
\hline \multirow{3}{*}{ Plant Species } & \multirow{3}{*}{ Dispersal Category } & \multicolumn{8}{|c|}{ Seedling Density } \\
\hline & & \multicolumn{4}{|c|}{ Upland } & \multicolumn{4}{|c|}{ Lowland } \\
\hline & & 0-Year-Old & 3-Year-Old & 5-Year-Old & Reference & 0-Year-Old & 3-Year-Old & 5-Year-Old & Reference \\
\hline Albizia adianthifolia & Gravity & 0 & 0 & 0 & 0.83 & 0 & 0 & 0 & 2.66 \\
\hline Brachylaena discolour & Wind & 0 & 0 & 0 & 0.67 & 0 & 0 & 0 & 0 \\
\hline Bridelia micrantha & Birds & 0.17 & 0.17 & 0.33 & 0 & 0 & 0.17 & 0.17 & 0.33 \\
\hline Canthium inerme & Birds/Mammals & 0 & 0 & 0 & 0 & 0 & 0 & 0 & 0.17 \\
\hline Celtis africana & Birds & 0 & 0 & 0 & 0.17 & 0 & 0 & 0 & 0.67 \\
\hline Clausena anisata & Birds & 0 & 0 & 0 & 0.50 & 0 & 0 & 0 & 0 \\
\hline Clerodendrum glabrum & Birds & 0 & 0 & 0 & 0.17 & 0 & 0 & 0 & 0 \\
\hline Combretum molle & Wind & 0 & 0 & 0 & 1.83 & 0 & 0 & 0 & 0 \\
\hline Croton sylvaticus & Birds/Mammals & 0 & 0 & 0 & 0 & 0 & 0 & 0 & 0.33 \\
\hline Cryptocarya woodii & Birds & 0 & 0 & 0 & 1.33 & 0 & 0 & 0 & 0 \\
\hline Dalbergia armata & Wind & 0 & 0 & 0 & 1.83 & 0 & 0 & 0.17 & 5.67 \\
\hline Dalbergia obovata & Wind & 0 & 0 & 0 & 8.67 & 0 & 0.17 & 0.33 & 1.16 \\
\hline Diospyros lycioides & Birds/Mammals & 0 & 0 & 0.67 & 0 & 0 & 0 & 0 & 0 \\
\hline Diospyros scabrida & Birds & 0 & 0 & 0 & 1.33 & 0 & 0 & 0 & 1.00 \\
\hline
\end{tabular}


Table 4. Cont.

\begin{tabular}{|c|c|c|c|c|c|c|c|c|c|}
\hline \multirow{3}{*}{ Plant Species } & \multirow{3}{*}{ Dispersal Category } & \multicolumn{8}{|c|}{ Seedling Density } \\
\hline & & \multicolumn{4}{|c|}{ Upland } & \multicolumn{4}{|c|}{ Lowland } \\
\hline & & 0-Year-Old & 3-Year-Old & 5-Year-Old & Reference & 0-Year-Old & 3-Year-Old & 5-Year-Old & Reference \\
\hline Erythrina sp. & Birds & 0 & 0 & 0 & 0 & 0 & 0.17 & 0.17 & 0 \\
\hline Euclea natalensis subsp. rotundifolia & Birds/Mammals & 0 & 0 & 0 & 0.17 & 0 & 0 & 0 & 0 \\
\hline Gymnosporia buxifolia & Birds & 0 & 0 & 0 & 0 & 0 & 0 & 0 & 0.50 \\
\hline Harpephyllum caffrum & Birds/Mammals & 0 & 0 & 0 & 0.17 & 0 & 0 & 0 & 0.17 \\
\hline Heteropyxis natalensis & Wind & 0 & 0 & 0 & 0.50 & 0 & 0 & 0 & 0 \\
\hline Kraussia floribunda & Birds/Mammals & 0 & 0 & 0.17 & 1.50 & 0 & 0 & 0.67 & 0.50 \\
\hline Macaranga capensis & Birds/Ballistic & 0 & 0 & 0 & 0 & 0 & 0 & 0 & 0.17 \\
\hline Manilkara discolor & Birds/Mammals & 0 & 0 & 0 & 0 & 0 & 0 & 0 & 3.67 \\
\hline Phoenix reclinata & Birds/Mammals & 0 & 0 & 0 & 0 & 0 & 0 & 0 & 0.17 \\
\hline Protorhus longifolia & Birds/Mammals & 0 & 0 & 0 & 1.00 & 0 & 0 & 0 & 2 \\
\hline Rauvolfia caffra & Birds/Mammals & 0 & 0 & 0 & 0 & 0 & 0.17 & 0 & 0 \\
\hline Rhoicissus tomentosa & Birds/Mammals & 0 & 0 & 0 & 0.17 & 0 & 0 & 0 & 0.83 \\
\hline Schrebera alata & Wind & 0 & 0 & 0 & 0 & 0 & 0 & 0.5 & 0.33 \\
\hline Sclerocarya birrea subsp. caffra & Mammals & 0 & 0 & 0 & 0 & 0 & 0.17 & 0 & 0 \\
\hline Sclerocroton integerrimus & Birds/Mammals & 0 & 0 & 0.33 & 0.33 & 0 & 0 & 0 & 0 \\
\hline Searsia lucida & Birds & 0 & 0 & 0 & 0 & 0 & 0 & 0.17 & 0 \\
\hline Searsia chirindensis & Birds/Mammals & 0 & 0 & 0 & 0.33 & 0 & 0 & 0.5 & 0 \\
\hline Searsia dentata & Birds & 0 & 0 & 0.17 & 0 & 0 & 0 & 0.83 & 0 \\
\hline Searsia rehmanniana & Birds & 0.33 & 0 & 0.17 & 0 & 0 & 0.5 & 0 & 0 \\
\hline Searsia pentheri & Mammals & 0 & 0 & 0.17 & 0 & 0 & 0 & 0 & 0 \\
\hline Senegalia caffra & Ballistic & 0 & 0 & 0.17 & 0 & 0 & 0 & 0 & 0 \\
\hline Strychnos mitis & Birds/ Mammals & 0 & 0 & 0 & 0 & 0 & 0 & 0 & 0.33 \\
\hline Tabernaemontana ventricosa & Birds / Mammals & 0 & 0 & 0 & 0 & 0 & 0 & 0 & 3.66 \\
\hline Tecomaria capensis & Wind & 0 & 0 & 0 & 0 & 0 & 0 & 0.83 & 0 \\
\hline Trema orientalis & Birds/Mammals & 0 & 0 & 0 & 0 & 0 & 0.33 & 0 & 0.17 \\
\hline Trichilia emetica & Birds/Mammals & 0 & 0 & 0 & 0 & 0 & 0.17 & 0.17 & 0.83 \\
\hline Vachellia natalitia & Wind & 0 & 0 & 0 & 0 & 0 & 0 & 0.17 & 0 \\
\hline Vangueria infausta & Mammals & 0 & 0 & 0 & 0.33 & 0 & 0 & 0 & 0 \\
\hline Zanthoxylum capense & Birds & 0 & 0 & 0 & 0.50 & 0 & 0 & 0 & 2.00 \\
\hline
\end{tabular}

For species authorship, see Table S2. 


\section{Discussion}

Monitoring and assessment of restoration success are critical steps needed to provide beneficial insight into restoration challenges and successes, which could guide the necessary management interventions and inform best practices in the future $[14,15,60]$. This study used measures of species richness, diversity, vegetation structure, IAP cover and ecological processes to assess the success of a climate change-driven community-based reforestation project in the city of Durban, South Africa. Some of the assessed indicators, such as vegetation structure and native tree recruitment, are progressing towards the reference habitat. It was also interesting to note that some of the pollination and seed dispersal categories were more abundant in habitats under restoration. However, low tree species richness and an increase in IAP cover with an increase in restoration age were identified as the critical threats that could compromise the project's success. Similar findings in the same area under restoration, but in completely different plots in the 3-, 4- and 5-year-old habitats were reported by Roy [61]. Other studies from Australia and Brazil also reported similar threats [14,62]. This suggests that possible management interventions are needed, and recommendations on some potential interventions are made below.

Douwes et al. [34] assessed the nursery tree seedling stock ready for planting at the Buffelsdraai Landfill Site and found that species that produce large fruits were the most dominant; for example, Erythrina lysistemon Hutch. (Fabaceae), Millettia grandis (E.Mey.) Skeels (Fabaceae), Syzygium cordatum Hochst. ex C.Krauss (Myrtaceae) and Vachellia natalitia E.Mey. (Fabaceae). Fruits of these species are easily noticeable, thus promoting their collection by tree-preneurs. Furthermore, these species are easy to propagate and are also fast-growing [34]. In the upland area, the three-year-old habitat had lower species richness and diversity, while the five-year-old habitat had lower species evenness and diversity. In the lowland area, the zero-year-old habitat had lower species richness and diversity. Although the number of species planted in the three- and five-year-old habitats is unknown, a greater number of fast-growing species in the nursery probably contributed to lower species richness, evenness and diversity in the restored compared with the reference habitat. To overcome this challenge, Douwes et al. [34] recommended that tree-preneurs should be incentivised to propagate less common species in order to increase species richness. In the Brazilian Atlantic Forest restoration study [23], this challenge was addressed by sourcing planting stock from both community-based seed collectors and professional seed collectors, to increase species richness.

Species richness, evenness and diversity indices (e.g., Simpson's evenness and Simpson's diversity) are widely used as indicators for assessing diversity between habitats under restoration and the reference communities, because they provide useful information on community state (e.g., $[15,16])$. However, when assessing restoration, these indicators need to be carefully interpreted, because diversity indicators might be similar or higher in the habitats under restoration than the reference, but their species composition significantly different [63]. For example, in the lowland area, the three-year-old habitat species richness, evenness and diversity showed no significant difference to the reference habitat, but these habitats differed significantly in terms of their species composition. Furthermore, tree density was not significantly different between the restored habitats and the reference habitat, but the tree height and canopy cover were visibly less established in the restored habitats in both the upland and lowland areas. However, the small size of the trees in the restored habitats $(0.38-0.52 \mathrm{~m})$ did not permit the measurement of parameters (e.g., diameter at breast height and canopy width) that could have allowed for proper structural comparisons between the reference and restored habitats.

The use of pioneer (fast-growing, but shade intolerant species) is the most recommended approach in forest restoration projects. These species create a canopy cover that shades out weeds, decreases fire risk and creates conditions suitable for the colonization of understorey and climax species (e.g., [64-66]). However, in the Brazilian Atlantic Forest, restoration of degraded lands using pioneer tree species resulted in the failure of many projects. When only pioneer trees were used, they matured and died before climax species could colonize the area [64]. In this study, all habitats under restoration in both 
the upland and lowland areas were dominated by pioneer tree species that have the ability to shade out weeds and create favourable conditions for understorey and climax species to colonize. Although climax and understorey species were present in the habitats under restoration, there were fewer climax and understorey species in the upland areas of the zero-and three-year-old habitats, respectively. We recommend that their abundance be increased through enrichment planting (planting of more species in areas that have been planted before) under the established canopies of pioneer species to avoid the situation reported by Rodrigues et al. [64].

Reforestation reports can sometimes contain information that is different from what was actually done in the field [14]. For example, in the reforestation of the rainforest in North Queensland, Australia, audits found that the sites only had half of the plantings documented in the project reports. Furthermore, the forested area was unlikely to develop into rainforest as a result of poor tree establishment, probably caused by a lack of ongoing site maintenance [14]. Therefore, it is critical to do a species assessment at an early stage so that necessary management interventions can be implemented to avoid poor tree establishment. For example, our study showed that an additional 14.8 and $60.8 \%$ of trees should be planted in the upland and lowland area for the zero-year-old habitat to achieve an average density of 1000 and 2000 trees per ha, respectively. A higher tree density in the upland area of the three- and five-year-old habitats ( 29.5 and $34.5 \%$ more trees, respectively) probably occurred as a result of dead tree replacement intervention. We suspect that tree replacement was carried out based on dead stem observations, because after a careful assessment (removal of litter around the base of dead tree stems) of the planted habitats that were more than a year older [67], it was found that most of the dead tree stems were coppiced at the base of the stem. Furthermore, in both the upland and lowland areas for the zero-year-old habitat, one month after planting (March 2015), some species lost their leaves accompanied by drying of stems, as a result of soil moisture stress, but re-sprouted eight months after. Therefore, the design of tree replanting interventions should be based on the outcomes of an assessment of tree mortality.

Mature native forests are characterized by a well-established structure that constitutes trees of different sizes, high canopy cover and understorey [68]. It takes decades to centuries for habitats under reforestation to develop the full structure of a mature forest [69]. Tree canopy cover is an important developmental stage in reforestation habitats, because it creates suitable conditions for forest succession by reducing irradiance, soil temperature and shading out weeds [10,70,71]. In reforestation habitats, tree canopy cover is a good indicator of forest development within the first decade following reforestation [10]. A full canopy cover can be achieved within two decades by planting more trees per hectare (e.g., 2500 trees/ha) [61]) and fast-growing tree species, especially in the tropical and subtropical areas [70,72]. In this study, the reference habitat had tall trees with a higher canopy cover compared with the reforested habitats. However, tree height and canopy cover in the three- and five-year-old habitats in both the upland and lowland areas showed rapid development. This rapid tree height and canopy cover development is attributed to the dominance of fast-growing species such as Bridelia micrantha (Hochst.) Baill. (Phyllanthaceae), E. lysistemon, D. obovata and V. natalitia [73]. The zero-year-old habitat was also dominated with fast-growing tree species in both the upland and lowland areas. It is expected that tree height and canopy cover will also develop rapidly in this habitat.

The colonization of reforested habitats by weeds (graminoids and forbs) and IAPs is a serious concern, because this can lead to restoration failure if weed/IAP management is inadequate/unsuitable $[4,14]$. It is therefore critical to continuously monitor the presence, expansion and distribution of IAPs. This is also because habitats that have been subjected to anthropogenic disturbance (e.g., agriculture) particularly in close proximity to cities are more vulnerable and highly likely to be invaded (e.g., [74]). Repeated removal of IAPs can increase native tree recruitment and tree species diversity [4]. Furthermore, past studies have found a decrease in IAP cover with an increase in natural forest tree canopy cover (e.g., [75]). Chromolaena odorata is now becoming a serious problem in the upland area of the five-year-old habitat and in the lowland area of both the three- and five-year-old habitats. At the Buffelsdraai Landfill Site, $C$. odorata plants are cut (about $5 \mathrm{~cm}$ from the ground) once a 
year, but there is no follow up to kill the trimmed stems via herbicide application. As a result, the stems were coppiced, creating impenetrable $C$. odorata thickets (see Figure S3). Repeated cutting coupled with a higher abundance of fast-growing pioneer species such as B. micrantha, E. lysistemon, D. obovata and $V$. natalitia [73] can lead to a decline in weeds and IAP cover. We therefore suggest that in recently (e.g., zero-year-old habitat) and future reforested habitats, IAPs should be uprooted and not cut, since these habitats are dominated by juvenile plants. Furthermore, all of the common IAPs present in the restored habitats have established biological control agents $[76,77]$. Therefore, biological control should also be prioritized as an alternative IAP management option.

Additionally, the presence of weeds (graminoids and forbs) and IAPs (e.g., C. odorata) can alter fire regimes by increasing fuel load, fire frequency and intensity [1,78]. Wildfire breakout is a major threat to forests and reforestation projects; therefore, fire prevention and suppression strategies should always be in place to avoid forest loss (e.g., [78-80]). For example, in 2008, forest and thickets were lost as a result of fire in Hluhluwe Game Reserve, South Africa [81]. One of the possible contributing factors to the large impact of this fire was the heavy infestation of $C$. odorata that contains essential oils in the leaves, making it highly flammable $[82,83]$ and capable of generating high flames that reach the tree canopy [11]. Wildfire breakout, particularly in autumn and winter, is one of the biggest threats to the Buffelsdraai Landfill Site, which can hamper reforestation success. If unmanaged, these fires can lead to seedling mortalities in forests [79]. At present, graminoids and forbs surrounding the restored habitats are removed to create fire breaks, and other fire management interventions include a fire fighting team that is always on standby to respond to any fire incident to curb fire-induced tree loss [84]. In the event that such mortalities are incurred, a stock of insurance trees is stored in the on-site nursery to replace lost trees [34].

Litter that accumulates on the forest floor is a basic component of almost all forests and is an essential contributor towards nutrient cycling [23]. Litter accumulation is regulated by multiple biological (e.g., tree age, plant species and forest composition) and climatic (e.g., rainfall, temperature and humidity) factors [23]. Higher levels of litter accumulation were observed in both the upland and lowland areas in the reference habitat than those under restoration. Higher litter accumulation levels in the reference habitat are attributed to its tall trees with wider canopies and a well-developed understorey. In the young, restored habitats, litter accumulation presumably takes a relatively longer time than the reference habitat as trees do not have fully developed canopies and hence do not shed much leaf litter (as reported in Rubiano-Cardona [23]). At present, the herbaceous understory layer is contributing more to litter accumulation in both the upland and lowland areas of the restored habitats. However, it is expected that as tree height and canopy increase with restoration age, coupled with the development of the understorey layer, this role will be fulfilled by the trees (as reported in Kanowski et al. [85]).

Numerous studies on reforestation have shown the importance of including tree species that are attractive to animals in order to promote key ecological process, such as pollination and seed dispersal $[66,85]$, that ensure the long-term stability of an ecosystem [86]. Our study showed that though most of the pollination and seed dispersal categories were abundant in habitats under restoration, some habitats lacked certain pollination and seed dispersal categories entirely. For example, there were fewer bee-pollinated species in both the upland and lowland areas of the five-year-old-habitat, while ballistic-dispersed species were scarcer in the lowland area of the zero-year-old habitat. We therefore recommend that during enrichment planting, these habitats should be supplemented with species belonging to categories that are lacking in order to increase their ecosystem functioning. Some studies have shown that mobile pollination and seed dispersal agents actively move between established and non-established patches $[87,88]$, thus increasing the chances of pollination and seed dispersal in non-established patches. Furthermore, the attractiveness of areas under reforestation to pollinators and dispersal agents develops over time and can be assessed as the trees mature. In our study, flowering, pollination and fruiting (Figure 4) observed in both upland and lowland areas of the three- and five-year-old habitats suggest that areas under restoration are 
becoming more attractive to pollinators and frugivores. An increase in bird species richness from 91-145 over a five-year period [34] supports this claim.

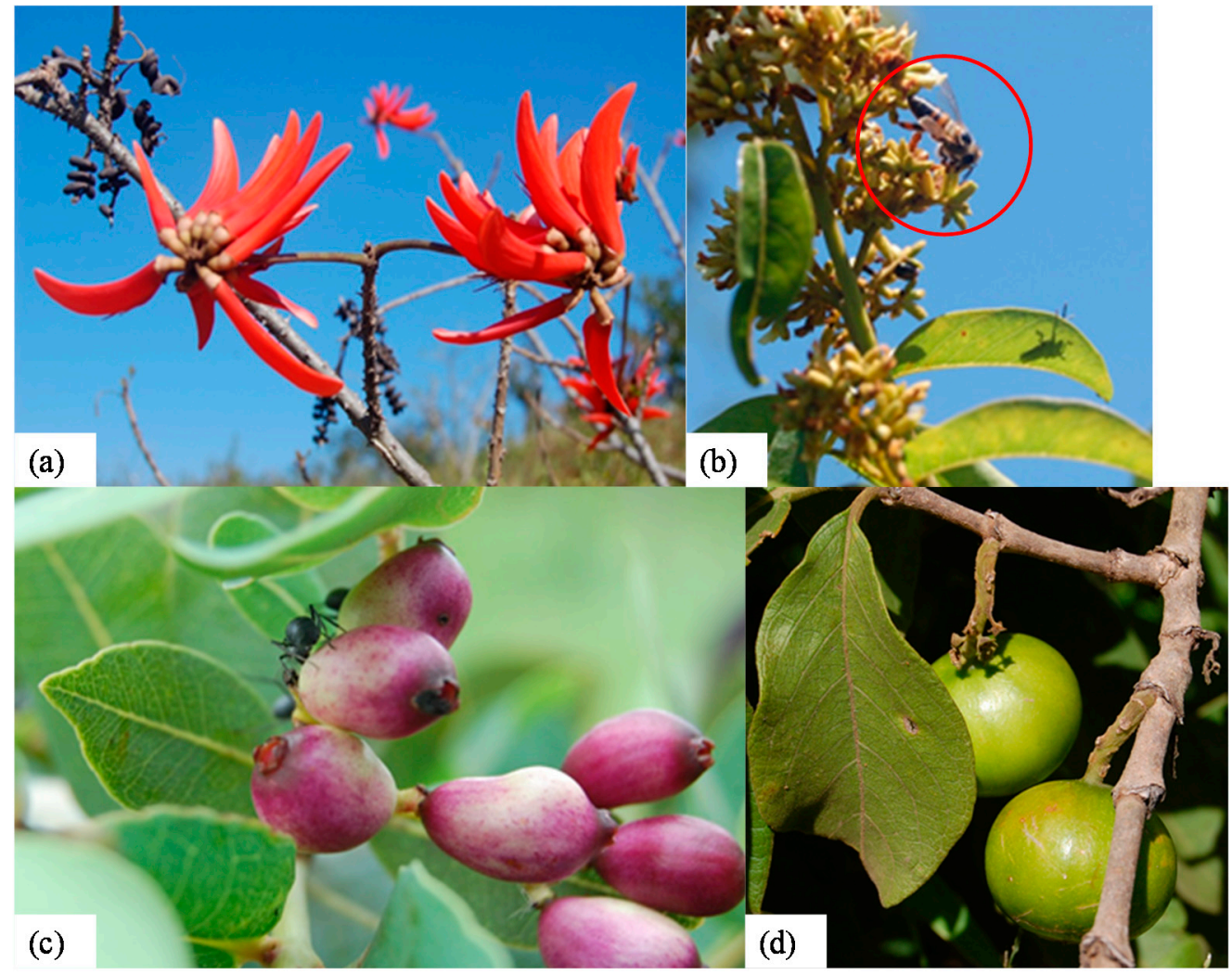

Figure 4. Flowering, pollination and fruiting in the three- and five-year-old habitats. (a) Erythrina lysistemon with flowers and pods; (b) bee pollination (within the red circle) on a Dalbergia obovata flower; (c) Syzygium cordatum fruits; and (d) Vangueria infausta fruits.

Seed dispersal is the last phase in the plant reproductive cycle and the first phase in the process of population renewal [89]. As a result, seedling recruitment is considered to be one of the key factors that determine the success of the long-term vegetation restoration [86]. Restoration habitats that are adjacent to the existing remnant forest are more likely to recover quickly as a result of colonization by animal seed dispersers $[18,20,29]$. However, the recruitment of animal-dispersed tree seedlings is higher in the established habitats [90]. In this study, habitats under restoration were adjacent to the reference habitat, and animal-dispersed seedling richness and abundance increased with an increase in restoration age. The lowland areas in both the three- and five-year-old habitats had higher seedling richness compared with the upland area (12 spp. vs. eight spp. and eight spp. vs. one spp.). A higher seedling richness in the lowland areas could be attributed to microclimate conditions that are conducive for seedling recruitment, created by tall trees with wider canopy cover (as reported in [70]). The recruitment of animal-dispersed species in these areas showed that frugivores are moving into areas under restoration and are most likely attracted by perches (established trees) and food (nectar and fruits). An increase in bird species richness in restoration habitats supports a higher recruitment of bird-dispersed species. Most of the species that are mammal dispersed at Buffelsdraai Landfill Site are suspected to be dispersed by vervet monkeys (Cercopithecus pygerythrus F. Cuvier, 1821 (Cercopithecidae)) that move between the reference and restoration areas. In the restoration of mined coastal dune forest in Richards Bay, South Africa, Foord et al. [91] found that vervet monkeys influence succession in habitats under restoration, because they disperse viable seeds of different tree species. 


\section{Conclusions}

An important recommendation emanating from the present study is that reforestation success assessment should be carried out in the early stages of reforestation projects in order to understand the ecological development trajectories and to inform necessary management interventions, to maximise reforestation benefits $[18,20,61]$. The use of multiple indicators (e.g., vegetation structure, species diversity, ecological processes and IAP cover) also gave valuable insight into the ongoing ecological trajectories and enabled the identification of necessary management interventions. Flowering and fruiting of planted trees, seed dispersal and the creation of favourable microclimatic conditions conducive for native tree recruitment signify restoration success [18], and the habitats under restoration showed some signs of success as early as three years after planting. However, enrichment planting is needed in certain habitats due to low tree density and richness. Enrichment planting should prioritize tree species in pollination and seed dispersal categories that are lacking. Pollination and seed dispersal processes should be monitored during the flowering and fruiting period, so that species that lack pollinators and dispersers can be identified and their agents introduced on site if possible [19,86]. Most importantly, all of these indicators should form part of a long-term monitoring and evaluation strategy.

Supplementary Materials: The following are available online at www.mdpi.com/1999-4907/8/8/255/s1, Table S1: The total number of recorded species per habitat (in brackets) and the number of shared species across habitats; Table S2: Checklist of plant species found in the restored and reference habitats; Table S3: Invasive alien plants recorded in the restoration ( 0,3 and 5-year-old) and reference habitats; Figure S1: Species accumulation curves. Observed (S est-species estimation), abundance-based coverage estimator (ACE) and Chao1 species richness in the (a) 0-, (b) 3-, (c) 5-year-old and (d) reference habitats; Figure S2: The NMDS ordination plot showing the overall tree species composition per habitat in both upland and lowland sections of the study site, The NMDS was based on the Bray-Curtis similarity index computed using species abundance data; Figure S3: Dense thickets of Chromolaena odorata infestation (foreground) in the 5-year-old habitat (Picture taken by Mugwedi LF., 2015).

Acknowledgments: This research was supported by eThekwini Municipality through the Durban Research Action Partnership: Community Reforestation Research Programme and by the South African Research Chairs Initiative of the Department of Science and Technology and National Research Foundation of South Africa. The authors thank University of KwaZulu-Natal for research support. We thank Richard Boon, Nokuphila Buthelezi, Errol Douwes, Nondumiso Khumalo, Philisiwe Manqele, Fatima Moolla Alli, Kate Roy and Richard Winn for the logistics and technical support. Vuyani Cele, Sizwe Hlatshwayo, Nelisiwe Khumalo, Angelique Lazarus, Rerani Ramaano and Jabulile Vumisa are thanked for field assistance. We appreciate two anonymous reviewers for their useful and positive comments that improved the manuscript.

Author Contributions: Lutendo F. Mugwedi, Mathieu Rouget, Benis Egoh, Sershen, Syd Ramdhani and Rob Slotow conceived of and designed the study. Lutendo F. Mugwedi, Mathieu Rouget and Jorge L. Rentería contributed to the data collection. Lutendo F. Mugwedi wrote the original manuscript, while Mathieu Rouget, Benis Egoh, Sershen, Syd Ramdhani, Rob Slotow and Jorge L. Rentería reviewed and edited the manuscript.

Conflicts of Interest: The authors declare no conflict of interest.

\section{References}

1. Aronson, J.; Clewell, A.F.; Blignaut, J.N.; Milton, S.J. Ecological restoration: A new frontier for nature conservation and economics. J. Nat. Conserv. 2006, 14, 135-139. [CrossRef]

2. Clewell, A.F.; Aronson, J. Ecological Restoration: Principles, Values, and Structure of an Emerging Profession; Island Press: Washington, DC, USA, 2007.

3. Oldfield, E.E.; Felson, A.J.; Auyeung, D.S.N.; Crowther, T.W.; Sonti, N.F.; Harada, Y.; Maynard, D.S.; Sokol, N.W.; Ashton, M.S.; Warren, I.I.; et al. Growing the urban forest: Tree performance in response to biotic and abiotic land management. Restor. Ecol. 2015, 23, 707-718. [CrossRef]

4. Simmons, B.L.; Hallet, R.A.; Sonti, N.F.; Auyeung, D.S.N.; Lu, J.W.T. Long-term outcomes of forest restoration in urban park. Restor. Ecol. 2016, 24, 109-118. [CrossRef]

5. Society for Ecological Restoration International Science and Working Policy Group (SER). The SER International Primer on Ecological Restoration. 2004. Available online: http://c.ymcdn.com/ sites/www.ser.org/resource/resmgr/custompages/publications/SER_Primer/ser_primer.pdf (accessed on 19 October 2016). 
6. Suding, K.N.; Gross, K.L.; Houseman, G.R. Alternative states and positive feedbacks in restoration ecology. Trends Ecol. Evol. 2004, 19, 46-53. [CrossRef] [PubMed]

7. Van Andel, J.; Aronson, J. (Eds.) Front Matter, in Restoration Ecology: The New Frontier, 2nd ed.; John Wiley \& Sons, Ltd.: Chichester, UK, 2012.

8. Dorren, L.K.A.; Berger, F.; Imeson, A.C.; Maier, B.; Rey, F. Integrity, stability and management of protection forests in the European Alps. For. Ecol. Manag. 2004, 195, 165-176. [CrossRef]

9. Norden, N.; Chazdon, R.L.; Chao, A.; Jiang, Y.H.; Vílchez-Alvarado, B. Resilience of tropical rain forests: Tree community reassembly in secondary forests. Ecol. Lett. 2009, 12, 385-394. [CrossRef] [PubMed]

10. Suganuma, M.S.; Durigan, G. Indicators of restoration success in riparian tropical forests using multiple reference ecosystems. Restor. Ecol. 2015, 23, 238-251. [CrossRef]

11. te Beest, M.; Cromsigt, J.P.G.M.; Ngobese, J.; Olff, H. Managing invasions at the cost of native habitat? An experimental test of the impact of fire on the invasion of Chromolaena odorata in a South African savanna. Biol. Invasions 2012, 14, 607-618. [CrossRef]

12. Woodford, R. Converting a dairy farm back to rainforest: The Rocky Creek Dam Story. Ecol. Manag. Restor. 2000, 1, 83-92. [CrossRef]

13. Kanowski, J.; Catterall, C.P. Converting Stands of Camphor Laurel to Rainforest: What Are the Costs and Outcomes of Different Control Methods? Centre for Innovative Conservation Strategies, Griffith University: Nathan, Australia, 2007.

14. Kanowski, J.; Catterall, C.P.; Freebody, K.; Freeman, A.N.D.; Harrison, D.A. Monitoring Revegetation Projects in Rainforest Landscapes: Toolkit Version 3; Reef and Rainforest Research Centre Ltd.: Cairns, Australia, 2010.

15. Derhé, M.A.; Murphy, H.; Monteith, G.; Menéndez, R. Measuring the success of reforestation for restoring biodiversity and ecosystem functioning. J. Appl. Ecol. 2016, 53, 1714-1724. [CrossRef]

16. Ruiz-Jaén, M.C.; Aide, T.M. An integrated approach for measuring urban forest restoration success. Urban For. Urban Green. 2006, 4, 55-68. [CrossRef]

17. Wortley, L.; Hero, J.-M.; Howes, M. Evaluating ecological restoration success: A Review of the literature. Restor. Ecol. 2013, 21, 537-543. [CrossRef]

18. Monie, K.; Florentine, S.; Palmer, G. Recruitment and functionality traits as bioindicators of ecological restoration success in the Lurg Hills district, Victoria, Australia. Ecol. Process. 2013, 2. [CrossRef]

19. Menz, M.H.M.; Phillips, R.D.; Winfree, R.; Kremen, C.; Aizen, M.A.; Johnson, S.D.; Dixon, K.W. Reconnecting plants and pollinators: Challenges in the restoration of pollination mutualisms. Trends Plant Sci. 2011, 16, 4-12. [CrossRef] [PubMed]

20. Abiyu, A.; Teketay, D.; Glatzel, G.; Gratzer, G. Seed production, seed dispersal and seedling establishment of two afromontane tree species in and around a church forest: Implications for forest restoration. For. Ecosyst. 2016, 3. [CrossRef]

21. Kostel-Hughes, F.; Young, T.P.; Carreiro, M.M. Forest leaf litter quantity and seedling occurrence along an urban-rural gradient. Urban Ecosyst. 1998, 2, 263-278. [CrossRef]

22. Barrientos, Z. Dynamics of leaf litter humidity, depth and quantity: Two restoration strategies failed to mimic ground microhabitat conditions of a low montane and premontane forest in Costa Rica. Rev. Biol. Trop. 2012, 60, 1041-1053. [CrossRef] [PubMed]

23. Rubiano-Cardona, K.; Arcila-Cardona, L.F.; Jiménez-Carmona, E.; Armbrecht, I. Production, accumulation, and decomposition of leaf litter in a Colombian Subandean forest and neighboring areas of restoration. Bol. Cient. Mus. Hist. Nat. 2013, 17, 47-59.

24. Herrick, J.E.; Schuman, G.E.; Rango, A. Monitoring ecological processes for restoration projects. J. Nat. Conserv. 2006, 14, 161-171. [CrossRef]

25. Dixon, K.W. Pollination and restoration. Science 2009, 325, 571-573. [CrossRef] [PubMed]

26. Ruxton, G.D.; Schaefer, H.M. The conservation physiology of seed dispersal. Philos. Trans. R. Soc. Lond. 2012, 367, 1708-1718. [CrossRef] [PubMed]

27. Neuschulz, E.L.; Mueller, T.; Schleuning, M.; Böhning-Gaese, K. Pollination and seed dispersal are the most threatened processes of plant regeneration. Sci. Rep.-UK 2016, 6. [CrossRef] [PubMed]

28. Holl, K.D.; Loik, M.E.; Lin, E.H.V.; Samuels, I.A. Tropical montane forest restoration in Costa Rica: Overcoming barriers to dispersal and establishment. Restor. Ecol. 2000, 8, 339-349. [CrossRef]

29. White, E.; Tucker, N.; Meyers, N.; Wilson, J. Seed dispersal to revegetated isolated rainforest patches in North Queensland. For. Ecol. Manag. 2004, 192, 409-426. [CrossRef] 
30. Aide, T.M.; Zimmerman, J.K.; Pascarella, J.B.; Rivera, L.; Marcano-Vega, H. Forest regereation in a chronosequence of tropical abandoned pastures: Implications for restoration ecology. Restor. Ecol. 2006, 8 , 328-338. [CrossRef]

31. Reed, C.C. Keeping invasive plants out of restorations. Ecol. Restor. 2004, 22, 210-216. [CrossRef]

32. Padmanaba, M.; Corlett, R. Minimizing risks of invasive alien plant species in tropical production forest management. Forests 2014, 5, 1982-1998. [CrossRef]

33. Hernández, L.; Martínez-Fernández, J.; Cañellas, I.; de la Cueva, A.V. Assessing spatio temporal rates, patterns and determinants of biological invasions in forest ecosystems. The case of Acacia species in NW Spain. For. Ecol. Manag. 2014, 329, 206-213. [CrossRef]

34. Douwes, E.; Rouget, M.; Diederichs, N.; O’Donoghue, S.; Roy, K. Buffelsdraai Landfill SiteCommunity Reforestation Project; XIV World Forestry Congress: Durban, South Africa, 2015.

35. MacFarlane, D.; Harvey, J.; Hamer, M. Biodiversity Assessment of the Buffelsdraai Landfill Site Community Reforestation Programme; Report No. EP 08-01; eThekwini Municipality: Durban, South Africa, 2011.

36. Mucina, L.; Rutherford, M.C. The Vegetation of South Africa, Lesotho and Swaziland. Strelitizia 19; South African National Biodiversity Institute: Pretoria, South Africa, 2006.

37. Von Maltitz, G.M.; Mucina, L.; Geldenhuys, C.; Lawes, M.; Eeley, H.; Adie, H.; Vink, D.; Fleming, G.; Bailey, C. Classification System for South African Indigenous Forests; Report No. ENV-P-C 2003-017; Department of Water Affairs and Forestry, CSIR: Pretoria, South Africa, 2003.

38. Eeley, H.A.C.; Lawes, M.J.; Piper, S.E. The influence of climate change on the distribution of indigenous forest in KwaZulu-Natal, South Africa. J. Biogeogr. 1999, 26, 595-617. [CrossRef]

39. Kotze, D.J.; Lawes, M.J. Viability of ecological processes in small afromontane forest patches in South Africa. Austral Ecol. 2007, 32, 294-304. [CrossRef]

40. Statistics South Africa: 2011. Available online: http://www.statssa.gov.za/?page_id=3839 (accessed on 18 July 2016).

41. EThekwini Municipality. Buffelsdraai Rehabilitation Project Soil Survey Report. Environmental Planning and Climate Protection Department; eThekwiniMunicipality: Durban, South Africa, 2014.

42. Omary, A.A. Effects of aspect and slope position on growth and nutritional status of planted Aleppo pine (Pinus halepensis Mill.) in a degraded land semi-arid areas of Jordan. New For. 2011, 42, 285-300. [CrossRef]

43. Simmons, M.E.; Wu, X.B.; Whisenant, S.G. Responses of pioneer and later-successional plant assemblages to created microtopographic variation and soil treatments in riparian forest restoration. Restor. Ecol. 2012, 20, 369-377. [CrossRef]

44. Boon, R. Pooley's trees of eastern South Africa; Flora and Fauna Publication Trust: Durban, South Africa, 2010.

45. Van Wyk, B.; Van Wyk, P. Field Guide to Trees of Southern Africa; Struik Nature: CapeTown, South Africa, 2013.

46. Norton, D.A. Species invasions and the limits to restoration: Learning from the New Zealand experience. Science 2009, 325, 569-571. [CrossRef] [PubMed]

47. South Africa. National Environmental Management: Biodiversity Act (Act No. 10 of 2004) Alien and Invasive Species Lists, 2016; Government Printing Works (Government Gazette No. 40166): Pretoria, South Africa, 2016.

48. Mayfield, M.M.; Ackerly, D.; Daily, G.C. The diversity and conservation of plant reproductive and dispersal functional traits in human-dominated tropical landscapes. J. Ecol. 2006, 94, 522-536. [CrossRef]

49. Seidler, T.G.; Plotkin, J.B. Seed dispersal and spatial pattern in tropical trees. PLoS Biol. 2006, 4, e344. [CrossRef] [PubMed]

50. R Development Core Team. R: A Language and Environment for Statistical Computing; R Foundation for Statistical Computing: Vienna, Austria, 2014.

51. Colwell, R.K. EsitmateS V 9: Statistical Estimation of Species Richness and Shared Species from Samples. 2013. Available online: http:viceroy.colorado.edu/estimates/ (accessed on 5 August 2016).

52. Gotelli, N.J.; Colwell, R.R. Quantifying Biodiversity: Procedures and Pitfalls in the Measurement and Comparison of Species Richness. Ecol. Lett. 2001, 4, 379-391. [CrossRef]

53. Chacoff, N.P.; Vázquez, D.P.; Lomáscolo, S.B.; Stevani, E.L.; Dorado, J.; Padrón, B. Evaluating sampling completeness in a desert plant-pollinator network. J. Anim. Ecol. 2012, 81, 190-200. [CrossRef] [PubMed]

54. Magurran, A.E. Measuring Biological Diversity; Blackwell Publishing: Oxford, UK, 2004.

55. Venables, W.N.; Ripley, B.D. Modern Applied Statistics with S, 4th ed.; Springer: New York, NY, USA, 2002.

56. Hothorn, T.; Bretz, F.; Westfall, P. simultaneous inference in general parametric models. Biom. J. 2008, 50, 346-363. [CrossRef] [PubMed] 
57. Oksanen, J.; Blanchet, F.G.; Kindt, R.; Solymos, P.; Henry, M.; Stevens, N.; Wagner, H. Vegan: Community Ecology Package. R package Version 2.3-5. 2016. Available online: https://rdrr.io/rforge/vegan/ (accessed on 18 July 2017).

58. Cohen, J.S.; Rainford, S.K.-D.; Blossey, B. Community-weighted mean functional effect traits determine larval amphibian responses to litter mixtures. Oecologia 2014, 174, 1359-1366. [CrossRef] [PubMed]

59. Muscarella, R.; Uriarte, M. Do community-weighted mean functional traits reflect optimal strategies? Proc. Biol. Sci. 2016, 283. [CrossRef] [PubMed]

60. Florentine, S.K.; Gardner, J.; Graz, F.P.; Moloney, S. Plant recruitment and survival as indicators of ecological restoration success in abandoned pasture land in Nurcoung, Victoria, Australia. Ecol. Process. 2013, 2. [CrossRef]

61. Roy, K.E. Seeing the wood for the trees: An evaluation of the Buffelsdraai Landfill Community Reforestation Project. Master's Thesis, University of KwaZulu-Natal, Pietermaritzburg, South Africa, 2015.

62. Brancalion, P.H.S.; Viani, R.A.G.; Aronson, J.; Rodrigues, R.R.; Nave, A.G. Improving planting stocks for the Brazilian Atlantic Forest Restoration through communitybased seed harvesting strategies. Restor. Ecol. 2012, 20, 704-711. [CrossRef]

63. Jaunatre, R.; Buisson, E.; Muller, I.; Morlon, H.; Mesléard, F.; Dutoit, T. New synthetic indicators to assess community resilience and restoration success. Ecol. Indic. 2013, 29, 468-477. [CrossRef]

64. Rodrigues, R.R.; Lima, R.A.F.; Gandolfi, S.; Nave, A.G. On the restoration of high diversity forests: 30 years of experience in the Brazilian Atlantic Forest. Biol. Conserv. 2009, 142, 1242-1251. [CrossRef]

65. Goosem, S.; Tucker, N.I.J. Repairing the Rainforest, 2nd ed.; Wet Tropics Management Authority and Biotropica Australia Pty. Ltd.: Cairns, Australia, 2013.

66. Douterlungne, D.; Siddique, I.; Soto-Pinto, L.; Jímenez-Ferrer, G.; Gavito, M.E. Microsite determinants of variability in seedling and cutting establishment in tropical forest restoration. Restor. Ecol. 2015, 23, 861-871. [CrossRef]

67. Mugwedi, L.F.; Rouget, M.; University of KwaZulu-Natal, Pietermaritzburg, KwaZulu-Natal, South Africa. Personal communication, 2014.

68. Franklin, J.F.; Spies, T.A.; Van Pelt, R.; Carey, A.B.; Thornburgh, D.A.; Berg, D.R.; Lindenmayer, D.B.; Harmon, M.E.; Keeton, W.S.; Shaw, D.C.; et al. Disturbances and structural development of natural forest ecosystems with silvicultural implications, using Douglas-fir forests as an example. For. Ecol. Manag. 2002, 155, 399-423. [CrossRef]

69. Cunningham, S.C.; Mac Nally, R.; Baker, P.J.; Cavagnaro, T.R.; Beringer, J.; Thomson, J.R.; Thompson, R.M. Balancing the environmental benefits of reforestation in agricultural regions. Perspect. Plant Ecol. Evol. Syst. 2015, 17, 301-317. [CrossRef]

70. Wishnie, M.H.; Dent, D.H.; Mariscal, E.; Deago, J.; Cedeño, N.; Ibarra, D.; Condit, R.; Ashton, P.M.S. Initial performance and reforestation potential of 24 tropical tree species planted across a precipitation gradient in the Republic of Panama. For. Ecol. Manag. 2007, 243, 39-49. [CrossRef]

71. Coote, L.; Dietzsch, A.C.; Wilson, M.W.; Graham, C.T.; Fuller, L.; Walsh, A.T.; Irwin, S.; Kelly, D.L.; Mitchell, F.J.G.; Kelly, T.C.; et al. Testing indicators of biodiversity for plantation forests. Ecol. Indic. 2013, 32, 107-115. [CrossRef]

72. Elliott, S.; Navakitbumrung, P.; Kuarak, C.; Zangkum, S.; Anusarnsunthorn, V.; Blakesley, D. Selecting framework tree species for restoring seasonally dry tropical forests in northern Thailand based on field performance. For. Ecol. Manag. 2003, 184, 177-191. [CrossRef]

73. Mugwedi, L.F.; Universtiry of KwaZulu-Natal, Pietermaritzburg, KwaZulu-Natal, South Africa. Personal communication, 2014.

74. Alston, K.P.; Richardson, D.M. The roles of habitat features, distubance, and distance from pupative source populations in structuring alien plant invasions at the urban/wildlandinterface on the Cape Peninsula, South Africa. Biol. Conserv. 2006, 132, 183-198. [CrossRef]

75. Mandal, G.; Joshi, S.P. Invasion establishment and habitat suitability of Chromolaenaodorata (L.) King and Robinson. over time and space in the western Himalayan forests of India. J. Asia-Pac. Biodiverss 2014, 7, 391-400. [CrossRef]

76. Baars, J.R.; Neser, S. Past and present initiatives on the biological control of Lantana camara (Verbenaceae) in South Africa. Afr. Entomol. 1999, 1, 21-34. 
77. Zachariades, C.; Strathie, L.W.; Retief, E.; Dube, N. Progress towards the biological control of Chromolaena odorata (L.) R.M.King \& H.Rob. (Asteraceae) in South Africa. Afr. Entomol. 2011, 19, $282-302$.

78. Brundu, G.; Richardson, D.M. Planted forests and invasive alien trees in Europe: A code formanaging existing and future plantings to mitigate the risk of negative impacts from invasions. NeoBiota 2016, 30. [CrossRef]

79. Wang, X.; He, H.S.; Li, X. The long-term effects of fire suppression and reforestation on a forest landscape in Northeastern China after a catastrophic wildfire. Landsc. Urban Plan. 2007, 79, 84-95. [CrossRef]

80. Reyer, C.; Guericke, M.; Ibisch, P.L. Climate change mitigation via afforestation,reforestation and deforestation avoidance: And what about adaptation toenvironmental change? New For. 2009, 38, 15-34. [CrossRef]

81. Browne, C.; Bond, W. Firestorms in savnna and forest ecosystems: Curse or cure? Veld Flora 2011, 97, 62-63.

82. Goodall, J.M.; Erasmus, D.J. Review of the status and integrated control of the invasive alien weed, Chromolaena odorata, in South Africa. Agric. Ecosyst. Environ. 1996, 56, 151-164. [CrossRef]

83. Witkowski, E.T.F.; Wilson, M. Changes in density, biomass, seed production and soil seedbanks of the non-native invasive plant, Chromolaena odorata, along a 15 year chronosequence. Plant Ecol. 2001, 152, $13-27$. [CrossRef]

84. Douwes, E.; Roy, K.E.; Diederichs-Mander, N.; Mavundla, K.; Roberts, D. The Buffelsdraai Landfill Site Community Reforestation Project: Leading the Way in Community Ecosystem-Based Adaptation to Climate Change; eThekwini Municipality: Durban, South Africa, 2015.

85. Kanowski, J.; Catterall, C.P.; Wardell-Johnson, G.W.; Proctor, H.; Reis, T. Development of forest structure on cleared rainforest land in eastern Australia under different styles of reforestation. For. Ecol. Manag. 2003, 183, 265-280. [CrossRef]

86. McAlpine, C.; Catterall, C.P.; Nally, R.M.; Lindenmayer, D.; Reid, J.L.; Holl, K.D.; Bennett, A.F.; Runting, R.K.; Wilson, K.; Hobbs, R.J.; et al. Integrating plant- and animal-based perspectives for more effective restoration of biodiversity. Front. Ecol. Environ. 2016, 14, 37-45. [CrossRef]

87. Lundberg, J.; Moberg, F. Mobile link organisms and ecosystem functioning: Implications forecosystem resilience and management. Ecosystems 2003, 6, 87-98. [CrossRef]

88. Staddon, P.; Lindo, Z.; Crittenden, P.D.; Gilbert, F.; Gonzalez, A. Connectivity, non-random extinction and ecosystem function in experimental metacommunities. Ecol. Lett. 2010, 13, 543-552. [CrossRef] [PubMed]

89. Harper, J.L. Population Biology of Plants; Academic Press: London, UK, 1977.

90. Viani, R.A.G.; Vidas, N.B.; Pardi, M.M.; Castro, D.C.V.; Gusson, E.; Brancalion, P.H.S. Animal-dispersed pioneer trees enhance the early regeneration in Atlantic Forest restoration plantations. Nat. Conserv. 2015, 13, 41-46. [CrossRef]

91. Foord, S.H.; Van Aarde, R.J.; Ferreira, S.M. Seed dispersal by vervet monkeys in rehabilitating coastal dune forest at Richards Bay. S. Afr. J. Wildl. Res. 1994, 24, 56-59. 